\title{
Two management courses for senior/specialist registrars
}

\author{
Maureen O'Brien and Gary Sullivan
}

The recent reforms to the NHS have resulted in a need for management training to be a part of higher professional training. The trend towards competition within internal markets requires that all doctors become managerlally accountable for the quality and efficiency of their service (Waters, 1985). The need for management training has been recognised by the Collegiate Trainees' Committee (CTC, 1990, 1995). Some training schemes offer no organised management training, and some provide training as a short course (Reder, 1996). Many residential management courses are avallable, providing one or two weeks of intenstve training. Inevitably, the amount of management theory and techniques which can be learned on such courses is limited.

We describe two courses leading to a basic qualification (certificate) in management which last one year, but do not require the use of precious research sessions or special interest sessions. One is a distance learning course by the Open University Business School, and the other a course provided locally. Both provide a level of management training far beyond what can be achieved on a brief course, and allow those who develop an interest in management to proceed to a more advanced qualification.

\section{Open University Professional Certifi- cate in Management: B601 Managing Health Services}

This course was designed specifically to meet the needs of managers in the Health Service, whatever their professional background. The course runs from June to May or November to October.

\section{Course content and resources}

There are 18 course workbooks, each divided into three to five chapters. The course is divided into three broad areas: Managing Yourself \& Your Job, Managing Resources and Managing in the Wider Context. The syllabus covered is outlined below:

\section{Managing Yourself \& Your Job: \\ (1) Managing \\ (2) Some fundamental skills \\ (3) Effective communication \\ (4) Decision making}

\section{(5) Planning \\ (6) Control}

Managing Resources:

(7) Choosing your team

(8) Developing, appraising \& counselling staff

(9) Motivating your team

(10) Leading your team

(11) Managing information

(12) Managing finance

Managing in the Wider Contert:

(13) Organizational structures

(14) Culture \& conflict

(15) Responding to customers

(16) Managing for quality

(17) Managing change

(18) The health service manager \& the wider world

In addition, a selection of readings are provided, along with the course book: Understanding Organizations by Charles Handy. There is a 3 hour video divided into six video sequences, and six audio cassettes to support the workbooks by giving practical examples of how the course material can be applied.

The course also includes a 'Personal Computing Starter Pack' designed to enable anyone with no experience of computing to set up a PC and develop word processing and spreadsheet skills, using Works for Windows (not included, but available at a discount from the OU).

The teaching 'package' includes a tutor, who will arrange a series of tutorials (around 14 hours), usually on Saturday mornings. The tutor is also available for advice by phone or letter. There is also a weekend residential school, which is compulsory. Students are encouraged to set up work groups among themselves to encourage each other, and to find a 'mentor' at work with whom to discuss how the course can be applied at work. The mentor and the groups are optional, as are the tutorials.

\section{Assessment}

Seven tutor-marked assignments contribute $50 \%$ of the final mark, and a 3 hour end of course examination contributes the other $50 \%$. 
The examination consists of one essay-paper of 3 hours' duration. Candidates must write five essays out of a choice of ten.

\section{Overall impression}

The course is a well presented, integrated package. The emphasis is on applying the material to situations at work. The academic standard is not high for anyone who managed to cope with medical school. The course is estimated to take 8-12 hours per week for 11 months, but I spent about half that amount of time on it. Anyone doing the course must have access to a PC, but does not need to know how to use it in the beginning.

I shared my tutorial group with a GP trainee, a health visitor and a practice manager. Of the eight who started the course, only four made it to the end. The work groups proved to be impractical since we came from such a wide area. Although I found myself a mentor, the idea was not successful in my case, partly due to lack of motivation and partly due to a busy job.

In spite of the problems, I enjoyed the course. The residential school was the highlight, providing an opportunity to meet and share perspectives with managers from other public services and industry. and was as much a social as an educational event. The main advantage of this course is its flexdbility. You can fit the work around other commitments and will not need to use any study leave. I found it relevant to everyday problems of organisation in the NHS, and applicable to what I do, even though I have no formal managerial role.

The main disadvantage was the degree of isolation. Most of the work is done without the opportunity for discussion, although the assignment marks and tutor's comments give some feedback. I found it difficult to motivate myself to do the work at times, especially when it was competing against more 'immediate' pressures. If you do fall behind, it can be very difficult to catch-up and, being isolated, you can become disheartened. This may account for the high drop-out rate in the tutorial group.

Those successfully completing the course may become members of the Institute of Health Services Management. Those who remain enthusiastic can study for a further year to obtain the Professional Diploma in Management. This allows access to the second year of the Open Business School's MBA program for those who wish to study further.

The cost of $\mathrm{B} 601$ in 1996 is $£ 1170$, but tax relief reduces this to $£ 889$. Finding a sponsor reduces it further!

\section{Institute of Management Foundation Certificate in Management Studies}

This course was designed to meet the needs of (would-be) managers whatever their work con- text and professional background. The course ran through three academic terms on alternate Monday evenings with three one-hour lectures and included a weekend workshop with course work submitted at intervals throughout the academic year. It was recognised as being at level four for National Vocational Qualification (NVQ) and could lead to higher levels of Diploma in Management Studies and finally an MBA.

\section{Content and resources}

The course was divided into four key areas: Manage Operations, Manage Finance, Manage People and Manage Information. The syllabus is outlined below:

\section{Manage Operations}

Unit 1-Maintain and improve service and product operations.

Unit 2 - Contribute to the implementation of change in service products and systems.

\section{Mange Finance}

Unit 1 - Recommend, monitor and control the use of resources.

\section{Manage People}

Unit 1 -Contribute to the recruitment and selection of personnel.

Unit 2 - Develop teams, individuals and self to enhance performance.

Unit 3-Plan, allocate and evaluate work carried out by teams, individuals and self.

Unit 4 - Create, maintain and enhance effective working relationships.

\section{Manage Information}

Unit 1 - Seek, evaluate and organise information for action.

Unit 2 - Exchange information to solve problems and make decisions.

A personal portfolio manager book was provided outlining the four key areas, their unit subdivisions, and the elements of each unit. Reading lists were suggested and general texts on management in an organisation were recommended.

This course required 'evidence' of having carried out all these key areas within the area of the manager's responsibility. This 'evidence' constituted the course work throughout the year. It was first assessed by a course tutor and then by an external examiner. Any queries from the external examiner were given to the student for consideration. A time was then arranged for the student and examiner to meet and discuss these 
queries. There was no end of year examination as there was continuous assessment throughout the academic year.

The advantages of this course were that it occurred locally, which mean that tutors, students and library were accessible, it was cheaper at $\$ 300$. It was also diverse, i.e. not health service led, which was interesting and gave insight into management in industry and other public services. The accessibility of the course helped keep the mottvation going, however, 3 hours of lectures after a full day at work could be difficult. Most completed the course and some went on to the Diploma in Management Studies course.

\section{References}

Collegiate Trainees Committee (1990) The CTC Working Party report on management training. Psychlatric Bulletin, 14, 373-378.

- (1995) Position on structured training. Psychiatric Bulletin, 19, 455-458.

REDER, P. (1996) A management course for senior registrars. Psychiatric Bulletin, 20, 195-297.

WATERS. H. (1985) Management training for cliniclans. Brittsh Medical Journal, 291, 1294-1295.

Maureen O'Brien, Senior Registrar; and *Gary Sullivan, Senior Registrar, University of Wales College of Medicine, Department of Psychological Medicine, Whitchurch Hospital, Cardiff CF4 7XB

*Correspondence

\section{Seminars in Clinical Psychopharmacology Edited by David J. King}

Psychopharmacology is a key both to the understanding of the biological basis of severe mental illness and to the rational use of drugs in clinical psychiatry. This book is an excellent introduction to an ever-expanding and fascinating subject, linking relevant basic neuropharmacology to clinical practice. It aims to bridge the gap between the theoretical basis for the mode of action of psychotropic drugs and guidance on their clinical use, and should increase interest in and understanding of the drugs widely used in clinical practice. £20.00, 544pp., 1995, ISBN 0902241737

Available from bookshops and from the Publications Department, Royal College of Psychiatrists, 17 Belgrave Square, London SW1X 8PG (Tel. 01712352351 extension 146)

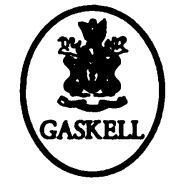

